\title{
Examining the Making and Movement of Speculative "Withness" in Young Children's A/r/tographic Collage
}

\author{
Jon M. Wargo \\ Department of Teacher Education, Special Education, Curriculum \& \\ Instruction, Boston College, USA \\ wargoj@bc.edu
}

\begin{abstract}
Mobilizing a/r/tographic inquiry with young children, this article focuses on a series of research-creation events to examine the making and movement of speculative "withness" inherent in creative production. Thinking with theories of posthumanism and visual studies, it diffractively reads across young children's making to refashion Szarkowski's elements of photography (the thing, the detail, the frame, time, and vantage point) as a/r/tographic renderings of the relational-aesthetic. Seeking to expand the sentient possibilities of 'seeing' and 'knowing' with young children, a series of provocations are presented to question the role of the image in young children's world making.
\end{abstract}

\section{Keywords}

a/r/tography - posthumanism - digital media - photography - visual studies - early childhood education - early learning - qualitative research methods

(C) JON WARGO, 2019 | DOI:10.1163/23644583-00401009 | THIS IS AN OPEN ACCESS ARTICLE DISTRIBUTED UNDER THE TERMS OF THE CC-BY 4.O LICENSE. 


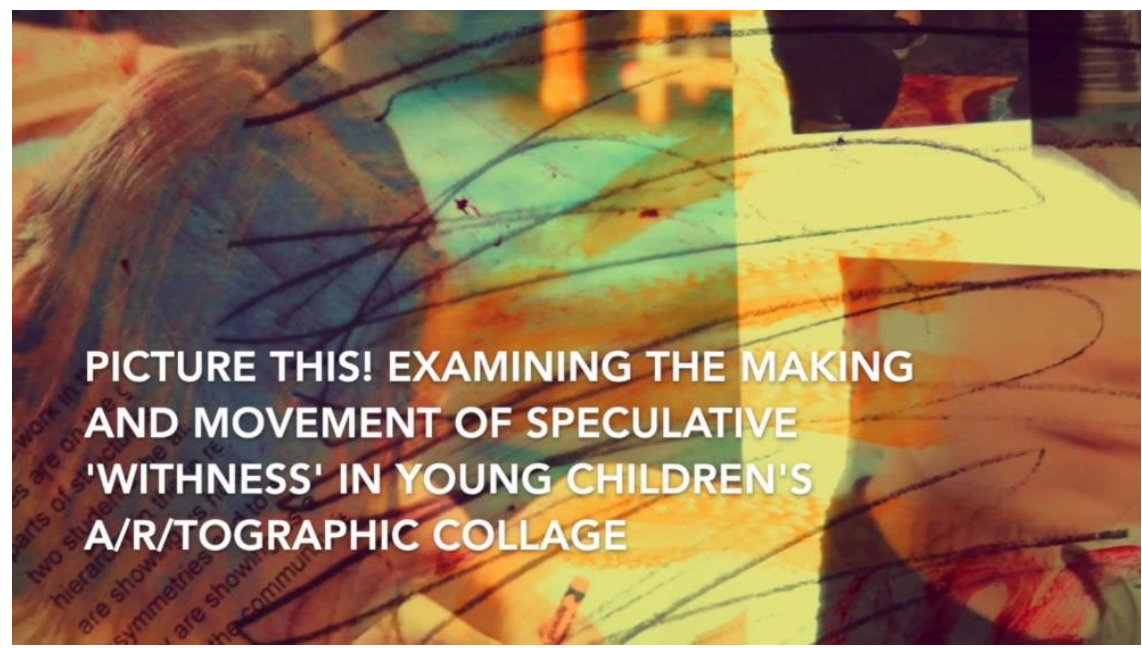

FEATURE John Wargo's article is based on the film 'Picture This!' which can be viewed here.

$\mathbf{1}$

\section{Introduction}

"Picture me!" Jacob, a young three implored. "Picture this." My iPhone is up, scaling the room documenting the creative compositions the 11 Pre- $\mathrm{K}_{3}$ (PreKindergarten for children who are 3 years old) students made in the 45 -minute block. Across the last 6 weeks, we've worked on integrating the art special into the classroom's problem-based inquiry concerning community. Disliking my silence, Jacob picked up his structure and moved it to the table that I was sitting at. "Look," he demands, "it's a camera!" I laugh, raise my iPhone and snap a shot of Jacob. "Ca-chunk!" Jacob mouths, clicking a pretend picture (see Figure 1). 


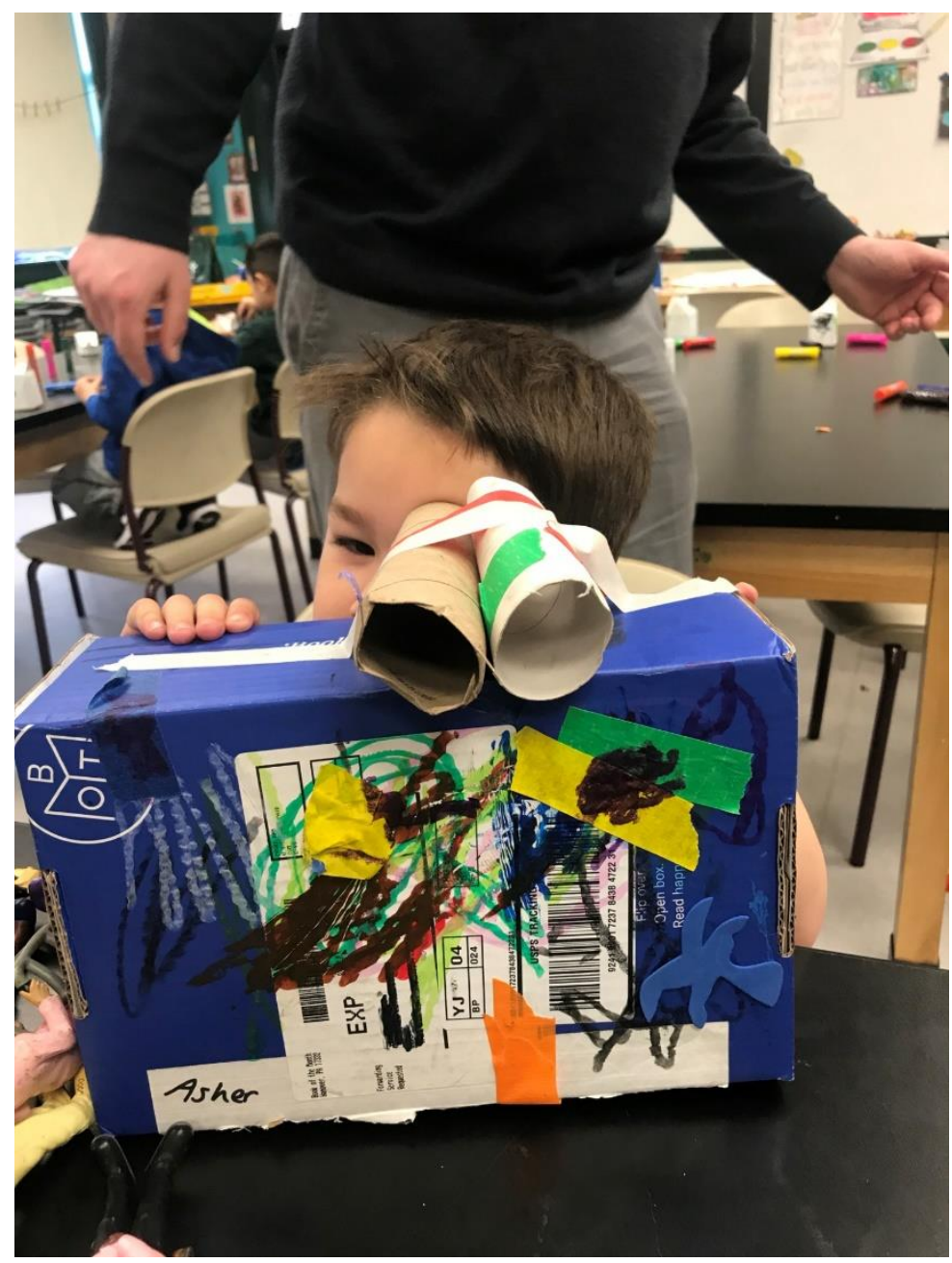

FIGURE 1 Jacob's Camera

"Hide your hands!" he howls, mimicking Ms. K, his PreK3 teacher, "better take it again!" Jacob turns the camera around and shows me the back. Made out of a blue cardboard box, the camera is loosely decorated with colored tape and tempera paint. "What do you see Jon?" he asked. "What do you see Jakey?" I echoed. It is in this speculative exchange, of seeing and speaking the relational (un)seen and the aesthetic (un)known, that I place this article and video snapshot. 
Photography and photo-based methods in early childhood research have largely worked as a form of narrative elicitation; or, to underscore children's "visual voice" (Burke, 2005). As Templeton (2018) writes, however, "A photo provides a sliver of insight, that when understood alongside other images and narrative fragments, can tell us about how children pronounce themselves and their place in the world" (p. 3). When I first entered the data archive for this article, I imagined that I would read child-produced photographs as descriptive recorded impressions that de-centered the human. How did the image, for instance, forward speculative visions? How could child-produced video underscore not what is or was, but what could be? Mobilized to document what and how children used video and the visual to articulate and modify their more-than-human social reality, photography served my larger study as a method for data generation. It shed light on aspects of a reality that I, as an adult researcher, could not see. Upon further reflection, however, I realized that I carried with me the understanding that the image and the technology (i.e., the camera) was passive and objective.

Taking Szarkowski's (1966) classic text The Photographer's Eye as my starting point, this paper examines how young children's a/r/tography - a relational-aesthetic arts-based approach to inquiry - challenges representational forms of photo-based documentation in early childhood research. Following Eisner (1995) and Barone (2001), this article argues for an inquiry that "endow $[\mathrm{s}]$ features of our experience with more than a single meaning" (Barone, 2001, p. 24). Seeking to expand the sentient possibilities of 'seeing' and 'knowing' with young children, I think with posthumanist conceptions of childhood (Kuby \& Rucker, 2016; Murris, 2016) to zero in on four of Szarkowski's (1966) focal elements: the thing itself/subject, detail and time, and the vantage point.

Looking at art as a material $\leftrightarrow$ discursive ${ }^{1}$ assemblage (e.g., an entanglement of space and place, and a meshwork of cutting-with bodies, movements, materials, and experiences), I ask the following:

\footnotetext{
${ }^{1}$ I use material $\leftrightarrow$ discursive throughout the article to highlight how the nature of materials and discourse are inseparable. "Discourse," as Barad (2008) contends "is not what is said; it is that which constrains and enables what can be said. Discursive practices define what counts as meaning statements.... Discursive practices produce, rather than merely describe" (p. 137). The bi-directional arrows, shifts in font, and breaks in text are purposeful discursive moves. They help think-with-theories of posthumanism and demonstrate the agential cuts and enacted agency of humans and the more-than-human.
} 
- How, when refracted through a/r/tography, do young children make sense of/in/with so-called visual waste (i.e., photos not selected as classroom documentation objects)?

- What new perspectives/concepts does this a/r/tographic examination of children cutting-with provide early childhood educators? How may it allow us to 'see' withness differently?

\section{3 \\ Thinking-with-A/r/tography: 'Seeing' Forwards through Young Children's Photography and Cutting-with-Video}

This project thinks with what Springgay, Irwin, and Kind (2005) call $\mathrm{a} / \mathrm{r} /$ tography, an arts-based form of thought that is enacted through living inquiry. $\mathrm{A} / \mathrm{r} /$ tography resides in the simultaneity of language/image/sound/time/space. It is theory-as-practice-as-process-ascomplication. $\mathrm{A} / \mathrm{r} /$ tography is the elision of knowing (theoria), doing (praxis), and making (poesis). Seeing the world through a process of art-making and writing, a/r/tography offers renderings, not findings, as possible avenues into exploring relational-aesthetic moments of thought. Renderings, thus, do not signal a particular concept, but rather the possibility of crafting meaning. A diffractive signal and interference to that which can and might be, not what is.

When refracted through Szarkowski's elements of photography, $\mathrm{a} / \mathrm{r} /$ tography serves as a diffractive pathway to be with the image. Diffraction, as Haraway (1992) explains,

Does not produce 'the same' displaced, as reflection and refraction do. Diffraction is a mapping of the interference, not the replication, reflection, or reproduction. A diffraction pattern does not map where differences appear, but rather maps where the effects of difference appear...the first invites the illusion of essential, fixed position, while the second trains us to more subtle visions.

HARAWAY, 1992, p. 300

For me this mapping of interference leads to a somewhere else. An ontoethico-epistemological space that forwards new lines of thought. Diffraction, hence, offered new pathways for expanding sentience and seeing with children in visual research.

As an arts-based researcher and former early years educator, I've come to render $\mathrm{a} / \mathrm{r} /$ tographic expression with young children through visual technologies. In earlier explorations (see, for example, Wargo, 2018), I

VIDEO JOURNAL OF EDUCATION AND PEDAGOGY 4 (2O19) 1-13 
examined how older children mobilized wearable technologies and videography to write with the human and more-than-human. With younger children, however, this interest transformed into a series of investigations tracing the uptake of the printed photographic image. Spliced through every day early years materials (i.e., charcoal, paper, markers) how did children, to borrow from Wohlwend and Thiel (2019) who call on Barad (2003), "cut with" the visual? How, when refracted through a posthuman and new materialist lens, does a/r/tography operate as an agentic act of becoming? How, as a researcher and videographer, do I transduce the 'cutting with' practice and assemblage through video? Taking Cristina Delgado-Vintimilla's tweet as impetus, I pondered how and in what capacity could photography and dialogic arts-based methods of making with children highlight the relational assemblage of 'seeing' possible futures (see Figure 2).

\section{What would happen if we approach documentation's stories as a form of world making rather than approaching them as accounts of children's meaning making?}

FIGURE 2 Vintimilla's Tweet

As Vintimilla asked, "What would happen if we approach documentation's stories as a form of world making rather than approaching them as accounts of children's meaning making."

Cutting-with, as the renderings will diffractively forward, is an a/r/tographic method for examining the socio-material dimensions of Barad's agential cut. It "looks for agency across components...[it] sees how things are not blankly waiting for human representation but are always / already conveying meanings" (Wohlwend \& Thiel, 2019, p. 174). Enmeshed in the larger 
$\mathrm{a} / \mathrm{r} /$ tographic assemblage, cutting-with emerged in the process of young children's collage. Rather than valuing what is/was representationally seen and heard, it shed light on the being/becoming inherent in arts-based experimentation. It also illuminated for me, as an artist and maker, new embodied understandings of my roles as researcher/teacher/viewer/and reader.

\section{$4 \quad$ Modes of Inquiry}

The work here draws on data from an empirical study examining diverse sites of young children's making. The larger project was interested in exploring how young children (ages 3-9) used digital technologies to 'make' a difference. Employing a "multi-sited sensibility" (Vossoughi \& Gutiérrez, 2014), I worked across three early learning spaces (a multi-age 1st-3rd grade classroom in the Midwestern United States, a parochial $\mathrm{PreK}_{3}$ classroom in Brighton, Massachusetts, and a 1st grade two-way immersion classroom in South Boston, Massachusetts). For the purposes of this short piece, I focus on 10 of the 11 students in the original $\mathrm{PreK}_{3}$ classroom and a series of researcher-initiated research-creation sessions of a/r/tographic inquiry that followed a yearlong investigation. ${ }^{2}$

\section{Generating Materials to Cut-With: Data Generation}

From selfies to blurry snapshots of twirly movement, children documented their participation in the larger project by taking digital photographs of our shared time together. The children then, at the close of the study, selected their favorite printed photos to document the research practice partnership. These were categorized by child and published in a photobook to present to parents. The remaining 73 photos, and those that I talk about here, were placed in the classroom waste basket. Retrieving them with a chorus of "...but that's garbage Jon" from the students, I pondered how this so-called visual waste may question the role of 'seeing' with young children.

\footnotetext{
${ }^{2}$ By research-creation, I draw on Springgay \& Rotas (2015) who examine it less as a folding of art into conventional humanist qualitative research and more as a material $\leftrightarrow$ discursive assemblage that moves beyond forms of representationalism into the not yet known.
}

VIDEO JOURNAL OF EDUCATION AND PEDAGOGY 4 (2O19) $\quad$ 1-13 
In analyzing the classroom's visual data, all photos were first aggregated by individual child and then interrogated as a larger corpus. Adapting Rose's (2012) language, I created an analytic matrix to examine Szarkowski's elements across the focal photographs each student selected (see Figure 3).

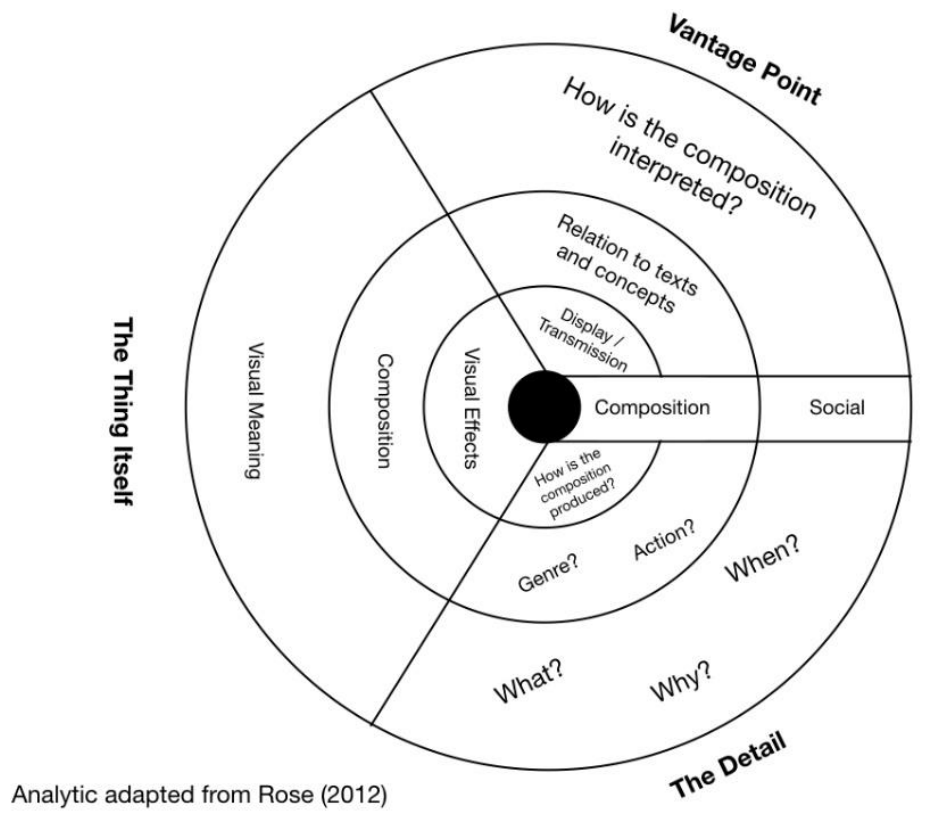

FIGURE 3 Adapted Analytic Matrix

The $11 \mathrm{PreK}_{3}$ children selected anywhere from 10-24 photographs each for a total of 200 photos. Months later, I returned to the 73 photos in the waste basket and coded them, independently, for focal themes and/or subjects. Perhaps unknowingly, these photos were quite similar. They included little to no environmental print, were focused on adult-interaction (between researcher and teacher, teacher and teacher), out-of-focus faces, and/or were framed by fingers and hands. While I do not have an accurate understanding of "how" these images came to be rendered as "garbage," I do know that Ms. K and her sing-song "Hide your hands!" played a large role in children's decision making.

Interested in the role of the image in making sense of the relationalaesthetic, I took the 73 photos back to the school a year later. Together, with 10 of the 11 original young children, I engaged in a series of three research- 
creation sessions. Outside of the visual "garbage" produced by the students, I brought with me a plethora of art materials (colored tape, Tempera makers, blocks, musical instruments) and fabricated researcher 'waste' of my own (i.e., field notes I printed on transparencies, photographs I took on my iPhone, etc.) It is in and through these sessions of the relational-aesthetic that I sought to render new ontologies of what it may mean to become with $a / r /$ tographic inquiry and de-center the human in photographic collage and video. Analyzing micro-moments of cutting with - material $\leftrightarrow$ discursive renderings of intra-action - I detail the dynamism of the research-creation event.

\section{$7 \quad$ Renderings}

Following in the spirit of $\mathrm{a} / \mathrm{r} /$ tographic inquiry, renderings are presented here to examine the relational-aesthetic of the human and more-than-human. Recognizing the limitations of the written word (grapheme), a researcherproduced video is included so as to visualize the "cutting-with" of the larger assemblage. While the video includes children's personal pictures and photographic stills of collage, it is backgrounded by field recordings, found sound, and stock video footage. Like the renderings below, these sections cut across Szarkowski's elements: the thing itself / subject, the detail / time, and vantage point. My goal in cutting-with a range of media is to highlight video's material capacity in, quite literally, cutting-with.

\subsection{Rendering 1: Cutting-with-The Thing / Subject}

A photo operates in a way that written observation in field notes or transcribing verbal interactions does not. A photo captures a subject. For Szarkowski (1966), the thing or the subject was an element that played with a fictional signifier of reality. The image, as a creation, theoretically points to a compositional figure that does not look back. How then, could we imagine the $\mathrm{a} / \mathrm{r} /$ tographic enterprise to compose a subject that never was? How do we cutwith-the subject?

10 now four-year-old students sit around a white light board. The children are quick to tell me that their PreK3 colleague, Kelvin, is not in PreK4. "He moved" April declared, "he isn't here." Although we were packed in a pile of stuff, the children were solely interested in catching up. "Where have you been?" "Who took these photos of me?" "Do you know Mr. Kevin (their PreK4 teacher)?" Sitting in the round, I started cutting pictures, placing transparencies on the light board and responded to each of the inquiries. "At school. You took these last year. Mr. Kevin was in my Teaching Reading class.

VIDEO JOURNAL OF EDUCATION AND PEDAGOGY 4 (2O19) $\quad$ 1-13 
I was his teacher." The conversation seemed to progress and our collaboration now seems choreographed. On the carpet, just in front of my person, I cut out a profile of a person. A fabric textured pattern of a body no longer in the frame. Carpet-shadow-light. Becca, without my consent picks up the spliced transparency and puts it over the whiteboard. Slowly but surely, students place "more stuffs" (their words, not my own) on top of the transparency. "These are the words. This is the story part." Jacob commanded. I smiled seeing the shift and primacy of alphabetic print as a tool to story children's schooled social worlds.

Brian turns on the light board.

Hayden turns off the white board.

I snapped a pic of the frame to document our process. As I did, Connell emerged on the scene and swiped the frame clean with two hands. "Again."

Cut images, colored writings, and torn photos moved toward the frame of the board. In seeing the images move, the pace of placed objects slow. I ask the students what we should call the piece. The process of naming became not about "who" was in the photo but rather the shape of the photographic event itself. "Mountains and Tornadoes" Griffin declared. "Yes!" Connell cheered, "we're on a trail and Griffin and Jon (me) and Ms. K's chair are mountains." "And here," Zoe said shuffling the cut-out words from field notes, "this is a plane and these are birds." "And these two guys. And these two guys," Jacob excitedly stated, "they're dead because they got pushed over mountains and the tornado."

\subsection{Rendering 2: Cutting-with-Detail/Time}

A photo, for Szarkowski is suggestive. The eye works to trace visible clues rendered possible by the image and builds the constellation of yet-to-be discovered meaning. $\mathrm{A} / \mathrm{r} /$ tographic inquiry and cutting-with-collage renders forgotten details for young children. It signals the temporal dimensions of space and place, and unearths an archive of what was, what is, and what may be seen.

With each new swipe of hands, the emergence of the lightboard clears the frame. Tempera paint is smeared in this doing and leaves a visible skin that the new collage sits on. The frame is stretched, shrunk, and chaotically composed with finger swipes, tears, and the cutting-collecting-assembling sequence. Connell sits out of the circle with a series of photos. "Mr. R (Ms. K's paraprofessional), you, and Kelvin" he pointed. I assert that if he was going to 
use Kelvin's pictures I needed to put tape over his eyes as he is not here today to say it is OK. Connell continued to sort the images by subject.

In the center of the lightboard, Griffin patchworked a series of childproduced photos of me. "You," he points giggling, pointing to me. Purple tempera is added to the work by Zoe. Connell brings cut-out Kelvin to join the group. A two-dimensional mattering of photo transforms. "Oh, hello Jon," Connell voiced with cut-out-Kelvin. Cutting-out is different than cutting-with. "Kelvin," Connell continued, "You're not here. Kelvin's not here, Mr. R is not here." Hayden lifts the light board to clear the photos.

\subsection{Rendering 3: Cutting-with-Vantage Point}

Throughout our research-creation meetings, a low sing-song hum rings out for from Mr. Kevin's classroom. Sound stunts the still images and moves it with its tempo and timbre. "You don't know Silvia?" Connell asked. "No," I responded, "I just know the students in Mr. Kevin's class who were in Ms. K's class last year. I don't know the new kids." "No," Jakey refutes. "They're not new." An image's vantage point signals an obscurity of the past. A felt moment that when photographed, we reflexively feel and speculate with. "Felt Jesus!" April shouted. The centered picture here is not one that was in the child's photo waste, but one I took as a visual field note. "It's Easter now too!" April stated. The light board sits covered. I hover to snap a photo of the scene and young bodies rhythmically move in ritualized dance. The scene becomes an openended invitation of sensation, movement, and affect.

It's our last meeting and the children are growing less excited to engage with the remaining materials. Rather than framing a new image with waste, students worked to blackout the lightbox. The children work and write with the light to blacken the frame. Peaks and valleys of fieldnote text, scribbled lines patch the scene. Rather than a descriptive image, the observer is presented with shapes and hues. An atmosphere of making is presented as a mereological continuum. "Can you see?" April asks. "We can." Hayden asserted. A/r/tographic collage renders potential futures and unearths repressed memories. It makes relationships (with both humans and the morethan-human) perceptible. The visual - whether printed on photo paper or hand rubbed with pastel - has a mereological capacity.

$\mathrm{A} / \mathrm{r} /$ tography is not a locatable object or thing in the world, but a concept by which objects coalesce and become with. Artifacts of our previous time together were unearthed and students quickly stacked stories with their visual waste. The hues of light sneak through folds and creases of materials. The bell for lunch rings. baRRRRRRRingggggGGGGGG. "Do you want me to clear the board Jon?" Connell asked.

VIDEO JOURNAL OF EDUCATION AND PEDAGOGY 4 (2O19) 1-13 
Young children's photography, when examined as an a/r/tographic endeavor is an entangled field of material relations and ontological becomings. By allowing children to showcase what their 'making' of speculative futures entailed, the possibilities of what children communicated expanded. Unbound by language, photographic collage and remediated video provided students greater freedom to name and make a wide variety of human (e.g., the researcher) and more-than-human things (e.g., atmospheres of hue) as texts. Cutting-with became a corporeal enlivening of the felt body.

Despite entering the inquiry with a focus on with and withness, I leave the relay of the relational and the aesthetic thinking "without." The significance of without appears only in retrospective discovery, one with/out a temporal frame and extended through the performative. $\mathrm{A} / \mathrm{r} /$ tography is an ontological event. A sense of place and process is not represented by but produced with children/materials/time/space. To return to Szarkowski's elements, this paper's significance lies in embracing a/r/tography as a democratizing enterprise of thinking with the visual, one that sees photographic elements (e.g., vantage point and detail) not solely as objects but as relations to become with or without the child. As such, photography and the visual elicits methodological moments of impact as materials produce memories, emotions, and desires in their encounters with the human and more-thanhuman.

\section{References}

Barad, K. (2003) Posthumanist performativity: Toward an understanding of how matter comes to matter. Signs:Journal of Women in Culture and Society 28, 801-831.

Barone, T. (2001). Science, art, and the predispositions of educational researchers. Educational Researcher, 7(30), 24-28.

Burke, C. (2005). "Play in focus": Children researching their own spaces and places for play. Children Youth and Environments, 15(1), 27-53.

Eisner, E. (1995). What artistically crafted research can help us understand about schools. Educational Theory, 45(1), 1-6.

Haraway, D. (1992). The promises of monsters: A regenerative politics for inappropriate/d others. Cultural studies, 295-337.

Kuby, C. R., \& Rucker, T. G. (2016). Go be a writer! Expanding the curricular boundaries of literacy learning with children. New York, NY: Teachers College Press.

VIDEO JOURNAL OF EDUCATION AND PEDAGOGY 4 (2O19) 1-13 
Murris, K. (2016). The post-human child: Educational transformation through philosophy with picturebooks. London: Routledge.

Rose, G. (2012). Visual methodologies: An introduction to researching with visual material. Thousand Oaks, CA: SAGE.

Springgay, S. \& Rotas, N. (2015). How do you make a class room operate like a work of art? Deleuzeguattarian methodologies of research-creation. International Journal of Qualitative Studies in Education, 28(5), 552-572.

Springgay, S., Irwin, R. L., \& Kind, S. W. (2005). A/r/tography as living inquiry through art and text. Qualitative inquiry, $n(6), 897-912$.

Szarkowski, J. (1966). The photographer's eye. New York, NY: Little Brown \& Co.

Templeton, T. N. (2018). 'That street is taking us to home': young children's photographs of public spaces. Children's Geographies, 1-15.

Vossoughi, S., \& Gutiérrez, K. (2014). Studying movement, hybridity, and change: Toward a multi-sited sensibility for research on learning across contexts and borders. National Society for the Study of Education, $113(2), 603-632$.

Wargo, J.M. (2018). Writing with wearables? Young children's intra-active authoring and the sounds of emplaced invention. Journal of Literacy Research. $50(4), 5^{\mathrm{O} 2-} 5^{23}$. doi: $10.1177 / 1086296$ X1880288o.

Wohlwend, K. E., \& Thiel, J. J. (2019). From cutting out to cutting with: A materialist reframing of action and multimodality in children's play and making. In Kucirkova, N., Rowsell, J. and Falloon, G. (Eds.). The Routledge International Handbook of Learning with Technology in Early Childhood, pp. 170-181. 